\title{
Subjective Assessment of Concert Halls: a Common Vocabulary for Music Lovers and Acousticians
}

\author{
Alicia GIMÉNEZ(1), Rosa María CIBRIÁN ${ }^{(2)}$, Salvador CERDÁ(3) \\ (1) Departamento de Física Aplicada, Universitat Politècnica de València \\ Camino de Vera s/n, 46022 Valencia, Spain; e-mail: agimenez@fis.upv.es \\ (2) Departamento de Fisiología, Universitat de València \\ Blasco Ibańez 15, València, Spain; e-mail: Rosa.M.Cibrian@uv.es \\ (3) Departamento de Matemática Aplicada, Universitat Politècnica de València \\ Camino de Vera s/n, 46022 Valencia, Spain; e-mail: salcerjo@mat.upv.es
}

(received July 7, 2011; accepted July 17, 2012)

\begin{abstract}
In recent years we have interviewed members of the audience after musical performances and asked them to evaluate the acoustics of the concert halls. A group of 'music lovers' (with a high level of musical training and experience) and 'acousticians' (with a wide knowledge of the physical characteristics of sound transmission) also attended each performance and answered the same questions as the general public. This group thereby served as a control group when evaluating surveys of the general public. In this paper, the results obtained when analyzing these control group surveys are presented. This analysis shows that a common vocabulary exists between music lovers and acousticians when rating a hall, although the grouping of the questions for each factor depends on the training of the respondents.
\end{abstract}

Keywords: room acoustics, subjective evaluation.

\section{Introduction}

The main objective of room acoustics is to study the behavior of sound within a room. The study of room acoustics involves finding relationships between the geometric and acoustic characteristics of a room or hall using various acoustic parameters. The aim is to achieve the audition desired by the listener according to the purpose of the sound. An analysis of this specialized research requires an understanding the different 'techniques' that each researcher employs in an attempt to systematize the two approaches (objective and subjective) used in the study. In recent years we have interviewed members of the audience after musical performances and asked them to evaluate the acoustics of the concert halls. A group of 'music lovers' (with a high level of musical training and experience) and 'acousticians' (with a wide knowledge of the physical characteristics of sound transmission) also attended each performance and answered the same questions as the general public. This group thereby served as a control group when evaluating surveys of the general public.

In this paper, we focus on the analysis of the opinion of this control group composed of 'music lovers' and 'acoustic specialists'. Both groups have the capacity to evaluate the acoustics of the halls but they make their evaluations from two different perspectives: from a musical perspective or technical training. This is revealed in the differing evaluations of some of the items in the survey of subjective assessment of the halls that we used (Gimenez et al., 2011). And, especially in the relative importance that each group ('music lovers' and 'acoustic specialists') gives to some items over others. This differing evaluation of some aspects of the musical quality of the halls will be highlighted in this work.

Each author in the literature uses different methods to assess subjective perception. In 1952, PARKIN, Schoeles, and Derbyshire (1952) presented a study on reverberation times in British halls and included results of a survey of critics, music teachers, and composers. Blankenship, Fitzgerald, and Lane (1955) made in 1955 a subjective assessment of halls at the University of Texas by collecting the responses of architects, acousticians, and musicians. Beranek published a book entitled Music, Acoustics and Architecture in 1962 (BERANEK, 1962) which provided results from a large study conducted by the author in the late 1950s on the quality of acoustics in 54 concert halls throughout the world using the subjective assessments of mu- 
sicians, directors, and music critics. A list of 18 subjective effects was presented by Beranek in the conclusion of his study. Following this work, two major studies were carried out in which subjects attended a series of concerts in various halls. Hawkes and Douglas in a 1971 study (HAWkEs et al., 1971) asked music students and professional musicians attending live concerts to complete questionnaires with a set of 16 bipolar scales. The main result of this study was the definition of a subset of orthogonal subjective parameters for factor analysis: reverberance; balance and blend; intimacy; definition and brilliance. In a 1988 study by BARRON (1988) expert listeners (acoustic consultants) attended live performances in 11 British concert halls and completed a survey after each concert. This questionnaire was shorter than previous studies, but was designed in the light of findings from earlier studies. The study concluded that subjects made subjective assessments from two perspectives: those who prefer reverberation, and those who prefer intimacy. Barron compared these results with those obtained in laboratory tests by the Berlin group (summarized in CREMER et al., 1982). These results and the absence of musical experts in their study, led Barron to describe a third preferred type of subjective assessment that is linked to clarity. Gade used questionnaires in his research on the acoustics of musicians performing on stage (GADE, 1989a; 1989b). He asked a large number of musicians to indicate the items they regard as most important and the subjective responses were: reverberance; support; timbre; dynamics; hearing each other; and time delay. Gade grouped these subjective aspects into 'soloist' and 'ensemble' concerns. A study by Sotiropoulou, Hawkes, and Fleming in 1995 (Sotiropoulou et al., 1995) examined evaluations made by general concertgoers and used factor analysis to obtain four independent subjective factors: body, clarity, tone quality, and proximity. Cox and Shield made a notable study of the acoustics of the Royal Festival Hall in 1999 (Cox et al., 1999) and included a survey of the general public, comparisons between musicians playing instruments, as well as comparisons between non-musicians and experts (after attending many concerts). Unfortunately, the results only examined one hall.

To conclude this review of research conducted on subjective assessment using surveys over the last decade, we find that the most recent works of Beranek and colleagues (BERANEK, 2003; 2008; HidAKA et al., 2000) are used as the main reference. The main objective of this study was to obtain a quality ranking for opera and concert halls.

Many researchers have been making subjective assessments using laboratory tests (ANDO, 1977; CHOI et al., 2005; GilberT et al., 1995; Marmellota, 2010; OKano, 2002; Schroeder et al., 1974; YAMAGUChI, 1972; ZAHORIK, 2009). These results corroborate and complement those obtained with questionnaires and surveys. Published results are more accurate and closer to reality if they have been verified by various investigators using several experimental approaches (GADE, 2007). These results suggest that the functional efficiency of music halls can be examined from various points of view: the acoustician, musician, and the general public. It may be believed that these views should match as the joint efforts of architects and acousticians are intended to effectively satisfy the needs of the musician and concert-goer (regardless of their knowledge of acoustics and music). However, this is not necessarily true because psychological factors that exert a strong influence on musicians cannot be felt or understood by acousticians nor general listeners - and vice versa.

Our paper proposes to achieve the following:

- Define the terminology that enables music lovers to express their assessment of music halls.

- Define the terminology that enables acoustic specialists to express their assessment of music halls.

- Integrate the contribution of music lovers and acousticians in a common vocabulary.

For this purpose we assembled a group of experts composed of 'music lovers' from the Conservatory of Music of Valencia and 'acoustics' from the Universitat Politècnica de València. Assessments of halls through a survey were compared with those made by concertgoers attending the performances. The evaluation of the results of the survey to obtain the ranking of halls showed that the valuations of the public were similar to those of the experts but a little less rigorous, which was perfectly acceptable, and revealed that expert opinion was consistent with the general public and vice versa.

However, we also noticed a slight variation in the evaluation of the items in the survey between the two subgroups that made up the panel. So we decided to specifically address this issue and investigate these slight differences in appreciation of the musical quality between 'music lovers' and 'acousticians'.

\section{Methodology}

\subsection{Subjects}

The group of experts was formed of 26 individuals: 14 experienced acousticians (architectural acousticians, technical acousticians, consultants, university lecturers and researchers); and 12 music-lovers who although not experts in acoustics, nevertheless have considerable experience in music and were trained at the Valencia Music Conservatory.

\subsection{Halls}

In the Table 1 we show the main typological characteristics of the nine halls in which the expert group made evaluations. 
Table 1. Main typological characteristics of halls studied.

\begin{tabular}{|c|c|c|c|c|c|c|c|}
\hline Hall & $\begin{array}{l}\text { Year } \\
\text { built }\end{array}$ & Shape & Use & $\begin{array}{l}\text { Seating } \\
\text { capacity }\end{array}$ & $V\left[\mathrm{~m}^{3}\right]$ & $\begin{array}{l}\text { Vol./seat } \\
{\left[\mathrm{m}^{3} / \text { per. }\right]}\end{array}$ & $\mathrm{RT}(\mathrm{s})$ \\
\hline $\begin{array}{c}\text { Auditorio } \\
\text { de Ribarroja } \\
\text { (Valencia) }\end{array}$ & 1994 & rectangular & $\begin{array}{c}\text { theatre, opera, } \\
\text { dance and concerts }\end{array}$ & 783 & 7830 & 10 & 1.79 \\
\hline $\begin{array}{c}\text { Auditorio } \\
\text { de Benaguacil } \\
\text { (Valencia) }\end{array}$ & 1960 & $\begin{array}{c}\text { rectangular, } \\
\text { fan shaped } \\
\text { on two levels }\end{array}$ & $\begin{array}{l}\text { music band } \\
\text { concerts }\end{array}$ & 509 & 3480 & 6.9 & 2.25 \\
\hline $\begin{array}{l}\text { L'Auditori } \\
\text { de Torrent } \\
\text { (Valencia) }\end{array}$ & 1997 & $\begin{array}{l}\text { irregular } \\
\text { hexagonal }\end{array}$ & $\begin{array}{c}\text { conferences, } \\
\text { congresses, } \\
\text { concerts of all types, } \\
\text { opera and dance }\end{array}$ & 606 & 6430 & 10.6 & 1.87 \\
\hline $\begin{array}{c}\text { Palau de la Música } \\
\text { de Valencia }\end{array}$ & 1987 & $\begin{array}{c}\text { central stage } \\
\text { with upper } \\
\text { amphitheater, } \\
\text { side and front } \\
\text { boxes (shoulders) }\end{array}$ & $\begin{array}{c}\text { conferences, } \\
\text { congresses, } \\
\text { concerts of all types, } \\
\text { opera and dance }\end{array}$ & 1817 & 14700 & 8.1 & 2.42 \\
\hline $\begin{array}{l}\text { Paraninfo } \\
\text { Universitat } \\
\text { Politècnica } \\
\text { de València }\end{array}$ & 1978 & retangular & $\begin{array}{c}\text { conferences, } \\
\text { congresses } \\
\text { and soloist } \\
\text { musician concerts; } \\
\text { chamber orchestra } \\
\text { and chorus } \\
\end{array}$ & 385 & 2700 & 7 & 1.3 \\
\hline $\begin{array}{c}\text { Teatro La Unión } \\
\text { Musical de Lliria } \\
\text { (Valencia) }\end{array}$ & $\begin{array}{c}1951 \\
(1992)\end{array}$ & $\begin{array}{l}\text { fan-shaped } \\
\text { on two levels }\end{array}$ & $\begin{array}{c}\text { orchestra and } \\
\text { music band } \\
\text { concerts }\end{array}$ & 967 & 6287 & 7.3 & 1.43 \\
\hline $\begin{array}{l}\text { Teatro Principal } \\
\text { de Alicante }\end{array}$ & 1905-1915 & $\begin{array}{l}\text { italian theatre, } \\
\text { horseshoe shape } \\
\text { and boxes on } \\
\text { different floors }\end{array}$ & $\begin{array}{c}\text { theatrical } \\
\text { representations, } \\
\text { orchestra } \\
\text { and soloist } \\
\text { concerts, opera, } \\
\text { chorus and dance }\end{array}$ & 1102 & 4539 & 4.1 & 1.21 \\
\hline $\begin{array}{c}\text { Auditorio } \\
\text { de Castellón }\end{array}$ & 2004 & $\begin{array}{l}\text { irregular } \\
\text { trapezoidal shape }\end{array}$ & $\begin{array}{c}\text { conferences, } \\
\text { congresses, } \\
\text { concerts of } \\
\text { all types, } \\
\text { opera and dance }\end{array}$ & 1200 & 14850 & 12.4 & 2.43 \\
\hline $\begin{array}{l}\text { Basilica de Sant } \\
\text { Jaume Algemesi } \\
\text { (Valencia) }\end{array}$ & $\begin{array}{c}1500-1580 \\
(1985)\end{array}$ & $\begin{array}{c}\text { rectangular } \\
\text { apsidal nave, } \\
\text { semi-cylindrical } \\
\text { ceiling, side } \\
\text { corridors with } \\
\text { square chapels } \\
\text { and rectangular } \\
\text { hemispheric ceilings }\end{array}$ & $\begin{array}{l}\text { religious events } \\
\text { and organ, } \\
\text { orchestra, } \\
\text { chamber orchestra } \\
\text { and chorus } \\
\text { concerts }\end{array}$ & 640 & 12144 & 19 & 5.07 \\
\hline
\end{tabular}

\subsection{Questionnaires}

We have verified that the questionnaire is a valid instrument for evaluating the subjective perception of listeners in concert halls, and we have found a good correlation between experts and the public in general; although there is a slight tendency by the public to overvalue the acoustic quality of the halls (HIDAKA et al., 2000). Partial results have been discussed in various forums (GIMENEz et al., 2006a; 2006b). In these conferences, we have presented evaluations of some concert halls and an initial analysis of the data using factor analysis. The small number of surveys made in previous works has obliged us to use all the results without distinguishing the three types of listener mentioned above. As a result, we have a sufficient database of responses from 'music lovers' and 'acousticians' to present a partial result for these two groups. The ques- tionnaire for validating the subjective assessment of the concert halls (GIMENEz et al., 2006a; 2006b), contained 58 questions divided into six sections:

Section A: 'General aspects of the hall'. Background noise, visibility of the orchestra, comfort of the seating, architecture and decor, etc.

Section B: 'Detailed acoustic perception'. Characteristics of the psychoacoustic quality are assessed in this section.

Section C: 'Global acoustic perception' includes items about the global perception of the orchestra, global orchestral balance, and an evaluation of global acoustic perception in the hall.

Sections D, E and F: 'Sociological data', 'Musical preferences' and 'Commentaries' include a total of six questions. 
Table 2. Sections B and C of the questionnaire, adapted to the journal.

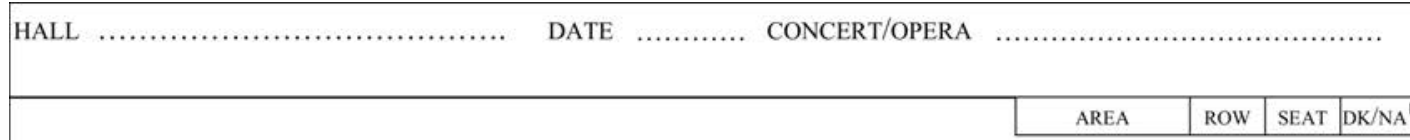

Section B: DETAILED ACOUSTIC PERCEPTION ${ }^{2}$

B01 Can you clearly distinguish the sounds of the different instruments?.

B11 Can you clearly distinguish the soloist (if there is one)? ..

B21 How do you perceive the orchestra overall? .

DO YOU CONSIDER THAT IN THIS HALL:

B41 High sounds predominate (high frequencies).

B42 Low sounds predominate (low frequencies).

B43 Sound is perceived equally from all directions.

HAVING HEARD THE MUSIC, THE SENSATION IT PRODUCES WITH RESPECT TO PROXIMITY OR DISTANCE FROM THE MUSICIANS IS THAT OF A HALL THAT IS:

B51 Large.

B52 Open.

B53 Wide.

YOU FIND THE SOUND OF THE HALL:

B61 Reverberating (persistence of the sound, the different sounds are superimposed)

B62 Dry (the sounds are not prolonged sufficiently)

B63 Intimate (the music gives the impression of being played in a small enclosure) ...

B64 Lively, rich, brilliant (richness of high tones that disappear slowly)..

B65 Warm (rich in low sounds that are perceived and distinguished clearly).

B66 Clear (details of the musical execution are distinguished separately)...

B67 Blurred (individualized sounds of the musical execution are confused and mixed) .... THE CONCERT HEARD IN THIS HALL PRODUCES THE SENSATION THAT THE MUSIC IS:

B71 Smooth, the opposite of rough...

B72 Exciting (predominance of high sounds and a loud level), the opposite is calm

B73 Balanced, the opposite is distorted..

B74 Loud (loud sound), the opposite is weak.

B75 Pleasant, the opposite is unpleasant.

B76 Light, the opposite is dense.

B81 Do you feel enveloped by the sound?

B82 If you do NOT feel enveloped, indicate the direction from which you hear the sound: Section C: OVERALL ACOUSTIC PERCEPTION

C01 Do you perceive the orchestra to be loud overall?...

C02 How balanced do you perceive the orchestra overall?...

INDICATE YOUR PERCEPTION OF THE DIFFERENT ELEMENTS OF THE ORCHESTRA:

C11 The string section dominates .

C12 The double bass section dominates.

C13 The woodwind section dominates.

C14 The brass section dominates.....

C15 The percussion section dominates

C16 The piano dominates.

C17 The soloist dominates.

C18 The chorus dominates.

C21 How do you classify the acoustics of this hall overall?
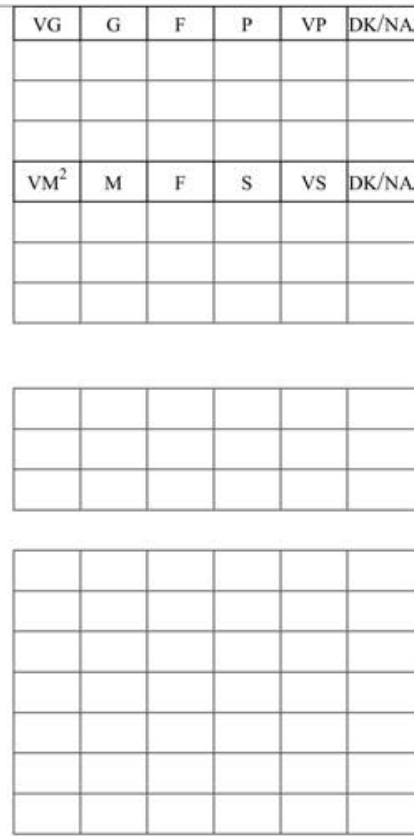

C31 How do the acoustics of this hall compare to another/other that you visit regularly?

C41 What other halls do you know whose acoustical quality is comparable with that of this hall?

${ }^{(1)}$ DK/NA: don't know/no answer or not applicable; VG: very good; G: good; F: fair; P: poor; VP: very poor. ${ }^{(2)}$ VM: very much; C: considerably; F: fairly; S: slightly; VS: very slightly. 
Each item can be rated from 1 to 5 points (corresponding to more or less agreement with the question) and the value 0 indicates a non-response. This work has not taken into account the questions in sections $\mathrm{A}, \mathrm{D}$, $\mathrm{E}$ and $\mathrm{F}$ as these questions are not specifically about a musical evaluation of the hall and include other collateral aspects such as comfort and decor. In this study, we have used the 23 questions in section B, as well as questions $\mathrm{c} 01$ and $\mathrm{c} 02$ that cover specific aspects of sound quality assessment (see Table 2).

\subsection{Procedure}

The group of experts was given set positions throughout the audience seating area of the halls and changed positions between acts. In this way, responses from the two groups corresponded to the same positions. The surveys were made during the following 14 musical performances (see Table 3 ).

\subsection{Statistical analysis}

The main applications of factor analysis are for reducing the number of variables and detecting structures in the relationship between the variables. The factor analysis we carried out consists of extracting the principal components by analyzing the correlations matrix for eigenvalues over one. We completed the process by rotating the factors using the varimax procedure. The questions are considered to be included within a factor when they have the highest rate of correlation in this factor (in absolute value) that exceeds $30 \%$. In this paper we have processed 246 surveys.

\section{Results and discussion}

Below are the results obtained by data reduction using factor analysis through the determination of the main components.

Table 3. List of concerts. Distribution of experts in the halls.

\begin{tabular}{|c|c|c|c|}
\hline HALL & CONCERT & Acousticians & Music Lovers \\
\hline \multirow[b]{2}{*}{$\begin{array}{l}\text { Auditorio de Ribarrroja } \\
\qquad \text { (Valencia) }\end{array}$} & Mozart (The Marriage of Figaro) & 5 & 6 \\
\hline & $\begin{array}{c}\text { C.M. von Weber (Der Freischütz); Strauss (Don Juan); } \\
\text { Brahms (Symphony No.2 in D Major) }\end{array}$ & 6 & 6 \\
\hline \multirow{2}{*}{$\begin{array}{l}\text { Auditorio de Benaguacil } \\
\qquad \text { (Valencia) }\end{array}$} & $\begin{array}{c}\text { Bernstein (Divertimento for Orchestra); } \\
\text { R. Miller (The Forest of Tears); } \\
\text { Rimsky-Korsakov (Scheherazade) }\end{array}$ & 6 & 7 \\
\hline & $\begin{array}{c}\text { M. Galvez-Taroncher (Night of Sobs); } \\
\text { M. Ohana (Concert for Piano and Orchestra); } \\
\text { Stravinsky (The Firebird) }\end{array}$ & 7 & 6 \\
\hline \multirow{2}{*}{$\begin{array}{l}\text { L'Auditori de Torrent } \\
\text { (Valencia) }\end{array}$} & G. Verdi (Rigoletto) & 14 & 12 \\
\hline & $\begin{array}{c}\text { E. Bermell (Dolores Tormo); } \\
\text { Bernstein (Divertimento for Orchestra); } \\
\text { Gershwin (Rhapsody in Blue); } \\
\text { F.A. Comos (Carmina Gueguel Massmanian Estelles); } \\
\text { J.G. Gomez-Deval (O Camino de Santiago); } \\
\text { M. Gould (Jericho) }\end{array}$ & 8 & 10 \\
\hline \multirow[b]{2}{*}{$\begin{array}{l}\text { Palau de la Música } \\
\text { de Valencia }\end{array}$} & $\begin{array}{c}\text { Haydn (Symphony "The Miracle", } \\
\text { Symphony "Drumroll") }\end{array}$ & 10 & 7 \\
\hline & $\begin{array}{c}\text { Strauss (Parergon zur Symphonia Domestica } \\
\text { for Piano and Orchestra, Op. 73); } \\
\text { X. Montsalvatge (Short Concert for Piano and Orchestra); } \\
\text { Ravel (Le tombeau de Couperin); } \\
\text { M. de Falla (El Amor Brujo) }\end{array}$ & 8 & 6 \\
\hline $\begin{array}{l}\text { Paraninfo de la Universitat } \\
\text { Politècnica de València }\end{array}$ & $\begin{array}{l}\text { Chopin (Cello Sonata in G minor, Op. 65); } \\
\text { C. Bersgen (Sonata for Flute and Piano); } \\
\text { J. Francaix (Trio for Flute, Cello and Piano); } \\
\text { K. Weill (Five Songs for Voice and Piano) }\end{array}$ & 14 & 12 \\
\hline \multirow{2}{*}{$\begin{array}{l}\text { Teatro de la Unión Musical } \\
\text { de Lliria, (Valencia) }\end{array}$} & $\begin{array}{c}\text { Beethoven (Symphony No. 1); } \\
\text { J.A. Valls-Subirats (Concert for Piano and Orchestra); } \\
\text { E. Chabrier (Rhapsody for Orchestra) }\end{array}$ & 13 & 12 \\
\hline & $\begin{array}{c}\text { I. Albéniz (Almera); M. Bautista } \\
\text { (Suite Generis for Tuba and Piano); } \\
\text { G. Faure (Dolly Suite Op 56); } \\
\text { A.von Zemlinsky (Trio); } \\
\text { J. Matitia (The Devil's Rag) }\end{array}$ & 5 & 10 \\
\hline Teatro Principal de Alicante & $\begin{array}{c}\text { Beethoven (Overture 'Egmont'); } \\
\text { P. de Sarasate (Bohemian Airs), (Carmen Fantasy); } \\
\text { Tchaikovsky (The Nutcracker Ballet Suite) }\end{array}$ & 13 & 10 \\
\hline Auditorio de Castellón & $\begin{array}{c}\text { Ravel (Alborada del Gracioso), (Tzigane); } \\
\text { C. Saint-Sans (Havanera Op 83); } \\
\text { I. Albéniz (Five Pieces of Iberia) }\end{array}$ & 8 & 10 \\
\hline $\begin{array}{c}\text { Baslica de Sant Jaume de Algemesí } \\
\text { (Valencia) }\end{array}$ & Handel ("The Messiah”) & 9 & 6 \\
\hline
\end{tabular}




\subsection{Acousticians}

We have obtained seven factors that explain $71 \%$ of the total variance. Each factor explains $14 \%, 12 \%$, $11 \%, 10 \%, 9 \%, 8 \%$ and $7 \%$, respectively. We can observe that some consecutive questions are grouped in the results from acousticians. This could be a consequence of the fact that the survey was designed by acousticians, and the nature of the authorship may also explain why the obtained factors are quite balanced. However, the groupings of non-consecutive questions are interesting. Interpretation is always perilous, but we suggest the following:

Factor 1: (14\%). This factor contains questions b72b76. It includes the adjectives: exciting, balanced, strong, pleasant and light. Therefore, we can consider it as a factor of pleasantness. The correlation factors are between 0.86 and 0.65 .

Factor 2: (12\%). Questions b51 to b53 evaluate the subjective dimension of the room, and question b71 relates to sensations of softness. The correlation factors are between 0.89 and 0.52 . This sensation may depend on the subjective perception of the 'size' of the room, because both impressions are related with early reflections.

Factor 3: (11\%). Questions b43, b64, c01 and c02 are listed in this factor. The correlation factors are between 0.90 and 0.52 . These are questions related to the perception of the orchestra, the directionality of the sound, and the presence of high frequencies. We can interpret this factor as relating to the perception of sound.

Factor 4: (10\%). Questions of clarity and the global perception of the orchestra are included in this factor (b01, b11, b21). It can be argued that acousticians analyze an orchestra's global perception from the point of view of clarity.

Factor 5: (9\%). Questions b41, b42 and b67. The correlation factors are between 0.86 and 0.46 . An unbalanced perception (high or low frequencies prevail) is listed together with the adjective 'cloudy'. We can say that imbalance is a masking effect or caused by a mixture of sounds (lack of balance).

Factor 6: (8\%). Questions b61, b65 and b81. The correlation factors are between 0.77 and 0.55 . The determination of an objective parameter that describes the perception of being enveloped by sound is a matter that is being researched at the moment. The grouping of reverberation, warmth, and the perception of envelopment may assist researchers interested in this topic (see factor 5 for music lovers).

Factor 7: (7\%). Questions b62, b63 and b66. The correlation factors are between 0.75 and 0.52 . This question corresponds to dry. Intimate (small room) and clear (separate details of the musical execution are distinguishable) are grouped in this final factor. These perceptions can be explained by a reduced level of sound reverberation.

\subsection{Music lovers}

We have also obtained seven factors that explain $62 \%$ of the total variance. Each factor explains $18 \%$, $8 \%, 8 \%, 8 \%, 7 \%, 7 \%$ and $6 \%$, respectively. In this case, factor 1 includes ten questions. The following three factors include three questions, and the last three factors only include two questions. A possible interpretation of each factor is:

Factor 1: (18\%) This pleasantness factor is similar to factor 1 for the acousticians (it includes almost all the questions in that factor), including: b43, b63-b66 and b71, b73-b76 (correlation factors between 0.44 to 0.78 ). The questions correspond to rating: intimate, live (brilliant), warmth, clearness, sensation of soft music, balance, high sonority, pleasantness, and lightness. More characteristics are included for this factor than in the case of the acoustic survey.

Factor 2: (8\%) Questions b11, b67, b72 and c02 (correlation factors between 0.76 to -0.59$)$. A term appears with negative correlation in this factor. Next to the cloudy term is the prevalence of high frequencies and the ease with which the soloist can be distinguished (negative correlation). Question c02 enquires as to the perception of a balanced orchestra. We named this factor 'precision of sound'.

Factor 3: (8\%) Questions b01, b21, c01 (correlation factors between 0.73 to 0.57 ). This factor regards perception of the orchestra: the ease with which the orchestra and instruments can be perceived and the orchestra's overall force.

Factor 4: (8\%) Questions b41, b42, b61 (correlation factors between 0.81 to 0.57 ). This factor is similar to factor five for the acousticians; namely, the unbalanced perception of high or low frequencies, and is grouped with 'reverberance'.

Factor 5: (7\%) Questions b52, b81 (correlation factors of 0.55$)$. The music lovers group feel enveloped by the sound. This fact, together with the observations made for acousticians in factor 6 , are interesting when designing an objective parameter for envelopment.

Factor 6: (7\%) Questions b51, b53 (correlation factors between 0.77 and 0.67 ). This factor includes the perceived 'size' of the room for music lovers.

Factor 7: (6\%) Questions b43 and b62 (correlation factor 0.43 and 0.88 ). The observation that the sound is equally perceived in all directions is grouped with dry. It could be argued that isodirectionality can be valued negatively by music lovers. 


\subsection{The common vocabulary}

It can be observed that the same questions appear in the seven factors found in both groups. However, the explanation of the variance in the case of acousticians is higher than that of the music lovers and the distribution of the questions differs. This shows that differences between acousticians and music lovers are very significant in the obtained factors. Even if we force the analysis to obtain just four factors, the differences between the groups remain the same. However, it is possible to see that there are factors supporting a similar explanation for both groups of subjects. Factors 1 which has been interpreted as a factor of "pleasantness' is common in both cases, as well as being the main factor (18\% for music lovers and $14 \%$ for acousticians). The 'size' factor also appears in both groups - but is more important for acousticians (12\%) than for music lovers (7\%). There is also a factor of being enveloped by sound that has similar percentages ( $8 \%$ and $7 \%$ ). Finally, the 'lack of balance' factor of the acousticians corresponds to an 'unbalanced perception' by the music lovers. However, the perception of the acousticians includes a group we call sound perception (11\%), that compares with the corresponding factor for the music lovers of the perception of the orchestra (8\%). Given these similarities, we performed a factor analysis with the least number of factors that explain about $50 \%$ of the variance and obtained four factors. Table 4 shows the components obtained in accordance with the questions studied and their correlations. Each factor explains 19\%, 11\%, 9\%, and 9\%, respectively. We can observe in this case that the contiguous questions are generally grouped together. We can consider the factors below as a common vocabulary:

Factor 1 (19\%): Quality factor about pleasantness. This factor incorporates the main factor of the group of acousticians and the music lovers group. The only question that is not included is b43 that appeared in F1 for music lovers (low correlation).

Factor 2 (11\%): Quality factor about global sound perception. This factor groups factors 3 and 4 of the acousticians (sound perception and clarity) and factors 2 and 3 of the music lovers (cloudy and perception of the orchestra). It also includes the question b81 about feeling enveloped by the sound that previously appeared in other factors (F6 for the acousticians and F5 for the music lovers).

Factor $3(9 \%)$ : Factor about room 'size' perception or subjective room size. This factor includes factor 2 for the acousticians, for which it is the second most important factor, and includes factors 5 and 6 for the music lovers (a less important factor for this group).
Factor 4 (9\%): This factor is about balance in frequencies from the musical point of view (reverberation included) that corresponds to factor 4 for the music lovers. It also groups factors 5 and 6 for the acousticians.

We have used the results obtained to propose a new grouping of factors for the subjective evaluation of concert halls. These new factors constitute a common view of the acoustic quality of concert halls by the two groups that represent the artistic and technical traditions of music listening.

Table 4. Questions at each factor in The Common Vocabulary.

\begin{tabular}{|c|c|c|c|}
\hline Factor 1 & Factor 2 & Factor 3 & Factor 4 \\
\hline b63. (0.69) & b01 (0.67) & b51 (0.68) & $\mathrm{b} 41(0.66)$ \\
\hline b64. (0.58) & b11 (0.67) & b52 (0.66) & b42 (0.73) \\
\hline b65. (0.58) & b21 (0.66) & b53 (0.77) & b61 (0.62) \\
\hline b66. (0.71) & b67 $(-0.48)$ & & \\
\hline b71. (0.53) & b81 (0.45) & & \\
\hline b72. (0.56) & c01 (0.39) & & \\
\hline b73. (0.70) & $\mathrm{c02}(0.48)$ & & \\
\hline \multicolumn{4}{|l|}{ b74. $(0.68)$} \\
\hline \multicolumn{4}{|l|}{ b75. (0.71) } \\
\hline b76. (0.63) & & & \\
\hline
\end{tabular}

The common language shared between musicians and acousticians is more similar to the language of musicians given that factor 1 of the musicians is practically identical to the common factor 1 for both acousticians and musicians; factor 4 of musicians is identical to the common factor 4 ; while the factors $2-3$ and 5-6 of the musicians only differ in one question with respect to the common factors 2 and 3, respectively, for both acousticians and musicians.

For concert halls and opera houses, BERANEK (1996) said that in recent years a common language of acoustics has been developed that emerges from the dialogue between musicians and acousticians.

In the literature, field studies into the multidimensional evaluation of auditorium acoustics by means of subjective surveys were performed with expert listeners (HAWKES et al., 1971, BARRON, 1998; BERANEK, 2003; 2008; HidAKA et al., 2000) and general audiences (Sotiropoulou et al., 1995; Cox et al., 1999). As far as we know, there is no specific work comparing surveys between music lovers and acousticians. Our results show that differences and similarities exist between these groups of experts - their general evaluations of the hall being similar but with each type of expert focusing on differing aspects.

The order of importance that we have found for acousticians is: pleasantness, subjective dimension, perception of the orchestra, clarity, lack of balance, 
envelopment and dry-intimate factor. The order of importance for music lovers is: pleasantness, precision of sound, perception of orchestra, lack of balance, openness of the hall, perceived size and iso-directionality. Although the terms that appear are common for subjective evaluations or halls it is worthwhile emphasizing the inclusion of the subjective dimension (acousticians) and perceived size (music lovers). A similar result was given by LOKKI et al., (2011) in which individually elicited attributes include factors such as openness and the width of sound.

However, the results provided by the experts are more consistent than the results of the general public (Cox et al., 1999). On further comparing the results of our two groups of experts (acousticians and music lovers) it can be seen that the acousticians are the more consistent of the two groups when consistency is evaluated with the percentage of explained variance in the factoral analysis ( $71 \%$ compared to $62 \%)$.

All of these differences indicate that the acousticians value the technical aspects by grouping them into balanced factors; while the music lovers make a grouping that includes nearly all of the items in one group (which therefore has greater weight).

Nevertheless, when a common language is considered and a set of four factors with $50 \%$ of the explained variance is established, we find that the first two factors can be considered as factors of overall perception - while the other two factors, refer to a more detailed analysis of sound. This twin point of view is apparent in early works on subjective evaluation (FISCHETTI et al., 1992). Moreover, our results agree with the view presented by Gade, in which the subjective characteristics are assembled into two groups: 'soloist' and 'ensemble' (GADE, 1989a; 1989b). Our results also coincide with the general view of BARRON (1988) who considers as important factors: reverberation, intimacy, and clarity.

Our results can also be compared with those of Lokki (LOKKI et al., 2011). Although Lokki obtains nine groups of characteristics, given the nearness of the resulting groups it is possible to make a grouping of just four: reverberance_1 (size of space); reverberance_2 (envelopment); definition; and a group that includes size of sound, loudness, separation, distance and openness (main dimension). These four factors can be related with the four factors that we have obtained as below:

- Factor 1................. Reverberance_2.

- Factor 2................. Main dimension.

- Factor 3.................. Reverberance_1.

- Factor $4 \ldots \ldots \ldots \ldots . . . . .$. Definition.

\section{Conclusions}

In this paper we present, using a subjective assessment survey, the qualities of sound perception most relevant for each group (musicians and acousticians) where their ratings are similar.

During the past five years we have surveyed a group of experts listening to performances in various concert halls in the region of Valencia in Spain. This group consists of musical and acoustic experts. We present the results of a factor analysis of the surveys.

The analysis of these surveys reveals varying results for 'music lovers' and 'acousticians'. While all the questions can be grouped into seven factors for both groups - the groupings are nevertheless distinct.

These results imply that educational training is an important factor in the evaluation of concert halls, even for expert groups:

- The number of factors - seven - is the same in both groups, but the group of acoustic experts shows more variance than the group of music lovers ( $71 \%$ compared to $62 \%$ ).

- For the acousticians the first four factors have percentages of between $14 \%$ and $10 \%$; while for the music lovers, the first factor with a factor of $18 \%$ is the only one with a value greater than $10 \%$.

- Factor 1 of the acousticians (14\%) includes five questions and factor 1 of the music lovers includes ten questions. However, there are questions in common.

- The questions are distributed almost equally (four or five) between all the factors for the acousticians; while for the music lovers the questions are encompassed in the first factor.

All of these differences indicate that the acousticians differentiate the technical aspects by grouping them into factors that contain contiguous questions, while the music lovers group almost all of the items into one factor (which therefore acquires greater weight). This may be caused by the fact that the survey was mostly designed by acoustic experts.

By analyzing all of the surveys together we have obtained a common vocabulary for musical and acoustic experts. We have found that contiguous questions are generally grouped together and that four factors are found and can be interpreted as follows:

- Factor 1: (19\%) - quality factor about sound perception.

- Factor 2: (11\%) - quality factor about perception of orchestra.

- Factor 3: (9\%) - factor regarding room 'size' perception (subjective room size or acoustical intimacy).

- Factor 4: $(9 \%)$ - factor regarding balance in frequencies from the musical point of view (reverberation included). 
The first two factors can be considered as factors of overall perception; while the other two factors refer to a more detailed analysis of sound. This common language between acousticians and music lovers is more similar to that of the musicians.

\section{Acknowledgments}

This study has been supported with FEDER funds. The Spanish Ministry of Science and Innovation also supported the present study in a coordinated investigation project framework (references BIA2003-09306C04 and BIA2008-05485). The translation of this paper was funded by the Universitat Politècnica de Valencia, Spain.

\section{References}

1. Ando Y. (1977), Subjective preference in relation to objective parameters of music sound fields with a single echo, J. Acoust. Soc. Am. 62, 6, December, 1436-1441.

2. Barron M. (1988), Subjective study of British symphony concert halls, Acustica, 66, 1-14.

3. BerAnEK L. (1962), Music acoustics \& architecture, John Wiley \& Sons, New York, NY.

4. BeraneK L. (1996), Concert halls and opera houses, Springer-Verlag, New York, NY.

5. BERANEK L. (2003), Subjective rank-orderings and acoustical measurements for fifty-eight concert halls, Acta Acustica united with Acustica, 89, 3, May/June, 494-508.

6. Beranek L. (2008), Concert Hall Acoustics, J. Audio Eng. Soc., 56, 7/8.

7. Blankenship J., Fitzgerald R. B., Lane R. (1955), Comparison of objective and subjective observations on music rooms, J. Acoust. Soc. Am., 27. 774-780.

8. Choi Y-J., Fricke F. R. (2005), Evaluation of the relative acoustic performance of two auditoria using measurements and auralization, Acta Acustica United with Acustica, 91, 1051-1062.

9. Cremer L., Müller H. A. (1982), Principles and applications of room acoustics, Vol. I, II, Applied Science Publishers, London.

10. Cox T. J., Shiels B. M. (1999), Audience questionnaire survey of the acoustics of the Royal Festival Hall, London, England, Acustica united with Acta acustica, 85, 547-559.

11. Fischetti A., Hemin Y., Jouhaneau J. (1992), Relations between Subjective Spatialisation, Geometrical Parameters and Acoustical Criteria in Concert Halls, Applied Acoustics, 37, 233-247.
12. GADE A. C. (1989a), Investigations of musician's room acoustic conditions in concert halls. Part I. Methods and laboratory experiments, Acustica, 69, 193-203.

13. GADE A. C. (1989b), Investigations of musician's room acoustic conditions in concert hall. Part II. Field experiments and synthesis of results, Acustica, 69, 249-262.

14. Gade A. C. (2007), Acoustics in halls for speech and music. Chapter 9, [in:] Handbook on Acoustics, J. Rossing [Ed.], Springer.

15. Gimenez A., Sendra J. J., Vela A., DaUmal F., Cibrian R., Zamarreńo T., Arana M., Romero J., Giron S., San Martin M. L., Cerda S., Galindo M., Aramendia E., Lacatis R., Bustamante R., San Martin R., Segura J., Muńoz M. S., Miralles J. L. (2006a), Process of developing a test of subjective response of listeners in general and musical experts, as an assessment tool of music perception in concert halls, auditoriums and theaters [in Spanish], Tecni-Acustica 2006, Gandia, ISBN 84-87985.

16. Gimenez A, Sendra J. J., Vela A., DaUmal F., Cibrian R., Zamarreńo T., Arana M., Romero J., Giron S., San Martin M. L., Cerda S., Galindo M., Aramendia E., Lacatis R., Bustamante P., San Martin R., Segura J., Muńoz M.S., Miralles J.L. (2006b), Responses from listeners and music experts to a survey to assess the perception of music in concert halls, auditoriums and theaters [in Spanish], Tecni-Acustica 2006, Gandia, ISBN 84-87985.

17. Giménez A., Cibrián R. M., Girón S., ZamarReńo T., Sendra J. J., Vela A., Daumal F. (2011), Questionnaire survey to qualify the acoustics of Spanish concert halls, Acta Acustica united with Acustica, 97, 6, November/December, 949-965.

18. Hawkes R. J., Douglas H. (1971), Subjective acoustic experience in concert auditoria, Acustica, 24, 235250.

19. Hidaka T., Beranek L. (2000), Objective and subjective evaluations of twenty-three opera houses in Europe, Japan, and the Americas, J. Acoust. Soc. Am., 107, 1, January, 368-383.

20. Lokki T., PÄtynen J., Kuusinen A., Vertanen H., Tervo S. (2011), Concert hall acoustics assessment with individually elicited attributes, J. Acoust. Soc. Am., 130, 2, 834-849.

21. Martellotta F. (2010), The just noticeable difference of center time and clarity index in large reverberant spaces, J. Acoust. Soc. Am., 128, 2, 654-663.

22. Okano T. (2002), Judgments of noticeable differences in sound fields of concert halls caused by intensity variations in early reflections, J. Acoust. Soc. Am., 111, 1, 217-229. 
23. Parkin P.H., Scholes W.E., Derbyshire A.G. (1952), The reverberation times of ten British Concert Halls, Acustica, 2, 97-100.

24. Schroeder M. R., Gottlob D., Siebrasse K. F. (1974), Comparative study of European concert halls: correlation of subjective preference with geometric and acoustic parameters, J. Acoust. Soc. Am., 56, 4, 11951201.

25. Sotiropoulou A. G., Hawkes R. J., Fleming D. B. (1995), Concert hall acoustic evaluations by ordinary concert-goers: I, multidimensional description of the evaluatios, Acustica, 81, 1-19.

26. Soulodre G.A., Bradley J.S. (1995), Subjective evaluation of new room acoustic measures, J. Acoust. Soc. Am., 98, 1, 294-301.

27. Yamaguchi K. (1972), Multivariate analysis of subjective and physical measures of hall acoustics, J. Acoust. Soc. Am., 52, 1271-1279.

28. ZAHORIK P. (2009), Perceptually relevant parameters for virtual listening simulation of small room acoustics, J. Acoust. Soc. Am., 126, 2, 776-791. 